\title{
Inferences of Carbon Dioxide in Present-Day Cell Culture Systems: An Unacknowledged Problem and Perspectives
}

\author{
Dubey AK', Lavanya $L^{2}$, Sadananda $D^{3}$, Gouthami \\ $K^{4}$, Elfansu $K^{5}$, Singh $A^{6}$, Singh $A^{7}$ and Singh $A_{K}^{8 *}$ \\ ${ }^{1}$ Department of Biotechnology, Indian Institute of \\ Technology Madras, India \\ ${ }^{2}$ Department of Biochemistry, REVA University, India \\ ${ }^{3}$ WPU Division, Institute of Wood Science and \\ Technology, India \\ ${ }^{4}$ School of Applied Sciences, REVA University, India \\ ${ }^{5}$ Division of Molecular Biology, J SS Academy of Higher \\ Education and Research, India \\ ${ }^{6}$ Medicinal and Process Chemistry, CSIR-Central Drug \\ Research Institute, India \\ TISF College of Pharmacy, India \\ ${ }^{8}$ Department of Pharmacology, Pennsylvania State \\ University, Penn State College of Medicine, USA
}

*Corresponding author: Ashok K Singh, Department of Pharmacology, Post-doctoral Research Trainee, Pennsylvania State University, Penn State College of Medicine, Hershey, PA, USA

Received: February 17, 2021; Accepted: March 13, 2021; Published: March 20, 2021

\begin{abstract}
The impact of cell culture technology has been immense in the field of research and pharmaceutical sciences. Suitable environmental conditions are paramount need in order to maintain the cell line in an in-vitro condition. Since the biological processes are highly susceptible to acid-base chemistry, variations among the factors will have a severe effect on cellular integrity that often leads to hypercapnia and senescence of the cells. $\mathrm{pH}$ regulation in the cell culture environment is a fundamental biological phenomenon of great significance for the growth and metabolism of cells. This review focuses on the implications of the two critical factors carbon dioxide $\left(\mathrm{CO}_{2}\right), \mathrm{pH}$, and their correlated effects in the mammalian culture system. Bicarbonate buffer plays a vital role in maintaining homeostasis as dissolved $\mathrm{CO}_{2}$ hydration occurs in bicarbonate $\left(\mathrm{HCO}_{3}{ }^{-}\right)$and $\mathrm{H}^{+}$equilibriums. If $\mathrm{pH}$ is not controlled, inhibition of $\mathrm{CO}_{2}$ causes acidification in the medium. In contrast, if $\mathrm{pH}$ is not regulated by integrating essential requirements, the equilibrium reaction shifts to the right towards the hydrogen ions that maintains the balance. Despite a few literatures exhibiting the role of carbon dioxide in cell culture, the present review distinguishes from them by showing the effects of $\mathrm{CO}_{2}$ in the in-vitro environment in maintaining the $\mathrm{pH}$ balance and cellular integrity. Thus, ensuring the proper mechanism of the utilization of $\mathrm{CO}_{2}$ and $\mathrm{pH}$ in the cell culture system will undoubtedly lead to the exploration of enormous concepts in the present crucial study.
\end{abstract}

Keywords: Hypercapnia; Senescence; Cellular metabolism; Bicarbonatebuffering system; Cell density; Intelligent fail-safe system

\section{Introduction}

The condition of growth is major characteristics of living organisms and impersonating this technology in-vitro could be possible through tissue culture, which requires appropriate environmental conditions and culture medium in either liquid or solid form. Growth of tissue or cell separation of an organism is capable of evidently growing in invitro conditions from living tissues. Various researchers are trying to give presentable work in the field of animal cell cultures [1]. Primary cells proliferating from organs or tissue in the in-vitro environment resemble the parental cells, which reflect changes in the growing cells, organs, or tissues. Cell proliferation requires a suitable environment and type of media for culturing, and with the right constituents, the process becomes more accessible to culture, which is meant to achieve [2].

Suitable environmental conditions are significantly responsible for cell maintenance and growth. Cell culture technique has a considerable advantage to manipulate and reproduce under optimum environmental conditions [3]. In a simulated environment, the cell culture system involves mainly factors such as $\mathrm{pH}$, ideal gas, temperature, and humidity, which allows cells to reproduce and grow. However, primary cells are typically preferred over continuous cell lines due to their physiological similarity in correspondence to the cells from living tissue. Furthermore, continuous cell lines undergo specific phenotypic and genotypic changes that lead to discrepancies during analysis. The cells obtained from living tissue in resemblance of primary cells, necessary for research can be studied for their functions, development, defects, metabolic regulations, cell physiology, and conditions affecting the tissue of interest [4].

While working with human tissue, which is frequent pathogenic, biosafety, is essential, especially with the range of equipment required in carrying out the isolation of cells; purification and culture, as described for tissue culture laboratory. However, precautions are required to avoid infection of species by microorganisms in order to preserve aseptic conditions. Understanding basic cell-culture handling techniques, including suitable choice of culture media, and cryopreservation can be an essential factor in maintaining cultures. Thus, culture techniques can be significantly employed for screening drugs, disease diagnosis, and the development of vaccines [5]. Despite the plethora of research articles published in correlating the $\mathrm{CO}_{2}$ and the cell culture system, there is no review so far present in the literature that describes the critical phenomenon of the effect of $\mathrm{CO}_{2}$ in the in-vitro environment in maintaining the cellular integrity of the cells in our knowledge. The idea of this study was considered when we observed in the growing fibroblast cell lines under experimental conditions with the variation of $\mathrm{CO}_{2}$ levels inside the incubator. As the level of $\mathrm{CO}_{2}$ dropped below the optimum value of $5 \%$, there were physiological changes observed in the morphology of the cell lines that finally lead to the loss of the adherence property. The color of the medium was also observed for the changes with variation in the $\mathrm{CO}_{2}$ levels, which could be due to the variation in the $\mathrm{pH}$, which is intercorrelated. This review emphasizes the correlative study of these two factors inside the cell culture system and their effects in-vitro.
Austin Therapeutics - Volume 6 Issue 1 - 2021

ISSN: 2472-3673 | www.austinpublishing group.com

Singh et al. (c) All rights are reserved
Citation: Dubey AK, Lavanya L, Sadananda D, Gouthami K, Elfansu K, Singh A, et al. Inferences of Carbon Dioxide in Present-Day Cell Culture Systems: An Unacknowledged Problem and Perspectives. Austin Therapeutics. 2021; 6(1): 1033. 
Table 1: Basic components of media for cell culture.

\begin{tabular}{|c|c|c|c|}
\hline S. No & Constituents & Functions & Source \\
\hline 1 & Amino acids (L-glutamine) & Acts as the initial precursor for protein synthesis and proliferation of cells. & [12] \\
\hline 2 & Inorganic salt $\left(\mathrm{Ca}^{2+}, \mathrm{Na}^{+}, \mathrm{K}^{+}\right)$ & Retains the osmotic balance. & [13] \\
\hline 3 & $\begin{array}{l}\text { Proteins and peptides (Albumin and } \\
\text { Fibronectin) }\end{array}$ & $\begin{array}{l}\text { Protein in the blood helps to bind water, salts, free fatty acids, hormones, and vitamins, and transport } \\
\text { them between tissues and cells. }\end{array}$ & [14] \\
\hline 4 & Antibiotics (Penicillin, Streptomycin) & Used to control the growth of microbes and fungal infections. & [15] \\
\hline 6 & Growth factors & Promoting cell differentiation and division. & [17] \\
\hline 7 & $\mathrm{pH}$ indicator (Phenol red) & For constant monitoring of media. & [18] \\
\hline 8 & Buffer solution (HEPES) & Regulating $\mathrm{pH}$, which is critical for optimum culture conditions. & [19] \\
\hline 9 & Natural buffer $\left(\mathrm{CO}_{2}\right)$ & For balancing $\mathrm{CO}_{2} / \mathrm{HCO}_{3}$, content in the cell culture medium. & [19] \\
\hline
\end{tabular}

\section{Cell Culture Media}

Cell culture media has significant advantages in the manipulation of the physiological environment (hormone and nutrient concentration) and physicochemical conditions ( $\mathrm{pH}$, temperature, $\mathrm{O}_{2}$, osmotic pressure, and $\mathrm{CO}_{2}$ tension) for cell proliferation. For both growth and maintenance, proper cell culture environment is a necessity [1]. For the cells to grow in-vitro and maintain their life, it is essential to get it supplemented with all types of nutrient media. The balanced salt solution contains a proper mixture of nutrients to regulate optimum osmotic pressure and provides essential nutrition to the cells. The components of the cell culture medium include inorganic salts, serum, glucose, vitamins, and amino acids. The serum is used as growth factors, hormones, and attachment factors [6]. In the enzymatic reactions, metal ions act as co-factors and improve cell adhesion. Phenol red used as $\mathrm{pH}$ indicator, at the range $\mathrm{pH}$ 7.0-7.4 changes from orange (red) to yellow in acidic conditions and turn to purple in basic condition. The buffer solution used for $\mathrm{pH}$ balancing products, e.g., the Bicarbonate/HEPES buffer for normal growth conditions, retains precise parameters such as temperature $\left(37^{\circ} \mathrm{C}\right)$, $\mathrm{CO}_{2}$ supplement (5\%) and relative humidity (95\%) [7]. Transformed cell lines can see better growth at the slightly acidic condition at $\mathrm{pH}$ 7.0-7.4 and, whereas the basic state, substantiates a $\mathrm{pH}$ range of 7.47.7. Carbon dioxide regulates the $\mathrm{pH}$ in the medium, and balances bicarbonate $\left(\mathrm{HCO}_{3}{ }^{-}\right)$and changes in the atmospheric $\mathrm{CO}_{2}$. A concentration of $5 \%$ of $\mathrm{CO}_{2}$ is usually maintained in the air, and $10 \%$ of $\mathrm{CO}_{2}$ is mostly used for experimental purposes [8]

Carbon functions as a source of energy, such as glutamine/ glucose. Organic compounds such as amino acids contain carboxyl $(-\mathrm{COOH})$ and amine $\left(-\mathrm{NH}_{2}\right)$ as a functional group along with the side chain [9]. Each amino acid contains R-group as specific [10]. The amino acid is the main component of the protein-synthesizing process. To promote the building blocks of proteins, it must contain vital elements of amino acid such as $\mathrm{N}_{2}, \mathrm{C}$, and $\mathrm{O}_{2}$. For many enzymes, vitamins act as co-factors, and its function is essential in advancing cell growth and survival. Cell death or loss of productivity occurs due to absorbed vitamins. e.g., Vitamin-C, Vitamin-B2, Vitamin-B6, Vitamin-B7, etc. Basal media contains serum, as a source of growth and adhesion factors regulating the permeability of cell membranes and acts as a carrier of proteins, enzymes, lipids, micronutrients, and some trace elements [11] (Table 1).

\section{Factors Affecting Cell Culture \\ Cell density}

Cell density is considered to regulate the amount of cell differentiation in culture $[20,21]$. The transport of minor nutrients relies solely on the density of the cells and decreases as the density of cells increases and vice versa [22-24]. The relationship between cell growth and nutrient transport rate is, however, less clear. One of the critical events supporting superlative cell proliferation is backed by enhanced membrane permeability for vital nutrients $[25,26]$. However, rises in the absorption of low molecular-weight nutrients are correlated with growth initiation. At the same time, some of these transport improvements are not causally related to differences between quiescent and proliferation. [27,28].

\section{Media exhaustion}

A media requires essential nutrients, hormones, and growth factors (serum), as well as osmotic pressure and $\mathrm{pH}$ maintenance for the cultural approach of medium affecting growth [1]. Once the organisms adhere to the cells, they grow faster and easily visible under the microscope. However, media, which includes serum, has some disadvantages such as specificity, standardization, high expense, stimulus or cellular activity, and growth inhibition. These downsides contribute to unintended results in cell culture, posing a considerable difficulty in performing cell culture experiments if the serum is not from the particular source, and can eventually lead to contamination [29]. Thus, contamination leads to changes in the color of the medium because of turbidity and changes in the $\mathrm{pH}$, invariably causing cell death [30].

Serum factors protect cells from general strain induced by shear forces, air bubbles, and toxic components operates in minute quantity identical to metal ions and oxygen radicals [31,32]. Antibiotics suppress the contamination, which would change the cell morphology and genotype. In biochemical experiments, antibiotics are found lethal to cells. The cultures found contaminated in the laboratory are reported to be harmful owing to the removal of antibiotics. Hence, it is imperative to protect the cell from any type of contamination occurring, such as air, temperature, light, etc. as it is irreversible in the culture [33].

\section{Cell deterioration}

Cell death may induce deterioration, which is the degradation of cultured cells; the frequent change in the required media could 
Table 2: $\mathrm{pH}$ range shows different colour changes.

\begin{tabular}{|c|c|c|}
\hline S. No. & Media colour & pH range \\
\hline 1 & Phenol red to yellow & Below 6.8 (too acidic) \\
\hline 2 & Red to pink & Above 7.0-7.7 (normal) \\
\hline 3 & Bright fuchsia & Above 8.2 (too alkaline) \\
\hline
\end{tabular}

include toxic substances [30]. Mostly primary cell culture is subjected to decay; threats are attributed to the unobserved microbes. However, the cultured cells should be adequately maintained to avoid risks of infections [34].

Unfavorable impact on cells in culture can attain through a variety of biological and chemical contaminants, ranging from destruction of the culture, phenotypic changes to relatively minor changes in morphology, mutation, or growth rate. In cell cultures, there are divergent approaches to detect and lessen the risk of biological or microbial contaminants [35]. Improper handling, glassware, or other types of consumables or sourcing of cell culture reagents are the familiar sources of chemical contaminants. The matter of chemical contamination reduces through best practices in sourcing and handling of such materials and by keeping away the use of volatile solvents within incubators while maintaining cell cultures [36]. Environmental conditions include microorganisms, most of which are bacteria, the reason why laboratory experiments/instruments, such as garments or gloves, may contribute to cell contamination [30].

\section{$\mathrm{pH}$}

Normally, cell lines can be grown well at $\mathrm{pH} 7.4$; among the cell lines, strains will differ, at very less variability. However, better growth is observed in transformed cell lines under acidic conditions such as $\mathrm{pH}$ 7.0-7.4. In basic state at $\mathrm{pH}$ 7.4-7.7, it prefers fibroblast cell lines typically [37].

The medium changes color during cell growth when $\mathrm{pH}$ varies due to the metabolites produced by the cells. A phenol red indicator is commonly used as a balance to the media for cell culture, which reflects shifts in $\mathrm{pH}$ in the medium when the color changes to yellow hue in the very low $\mathrm{pH}$ (acidic) range [6] (Figure 1 and Image 1). When $\mathrm{pH}$ is too high (alkaline), its color shows purple, whereas, under the proper physiological condition, the $\mathrm{pH}$ color appears to be in orangey-red hue [38] (Table 2).

\section{Temperature}

Without an ideal temperature, it is challenging to grow cells in the culture medium, while supplementation with the required nutrients and ideal temperature will facilitate cytogenesis; thus, temperature plays a crucial role in cell development [39]. As temperature rises, cells often proliferate, and enzyme molecules can speed up metabolism by moving quickly. At a certain point, the value of all these activities, such as denature of enzymes and co-factors, cell confluence, detrimental effect (damage), and high rate values, leads to the cease of cellular growth [40]. In the isolation medium, cells require a host primarily to maintain cell culture as the optimum temperature is necessary [41]. Each species has its optimum temperature for the division that defines the character containing limits in microbes, as of that species maintained for growth. Cellular metabolism functions at the aspect of their optimal values of heat to which the ability of cells are increased
Table 3: The optimum temperature for various cell lines.

\begin{tabular}{|c|l|c|c|c|}
\hline S. No & \multicolumn{1}{|c|}{ Type of cell line } & Source & Temp. $\left({ }^{\circ} \mathbf{C}\right)$ & Reference \\
\hline 1 & Spodoptera frugiperda (sf-21) & Insect & 27 & {$[41]$} \\
\hline 2 & Trichophusia ni (Tn-5) & Insect & 27 & {$[41]$} \\
\hline 3 & Chinese Hamster Ovary (CHO) & Mammalian & $36-37$ & {$[43]$} \\
\hline 4 & $\begin{array}{l}\text { Human embryonic kidney (HEK- } \\
\text { 293T) }\end{array}$ & Human & 37 & {$[44]$} \\
\hline 4 & HF 205 and HF 210 & Plant & 25 & {$[45]$} \\
\hline 5 & Spodoptera frugiperda (sf-9) & Insect & 27 & {$[46]$} \\
\hline
\end{tabular}

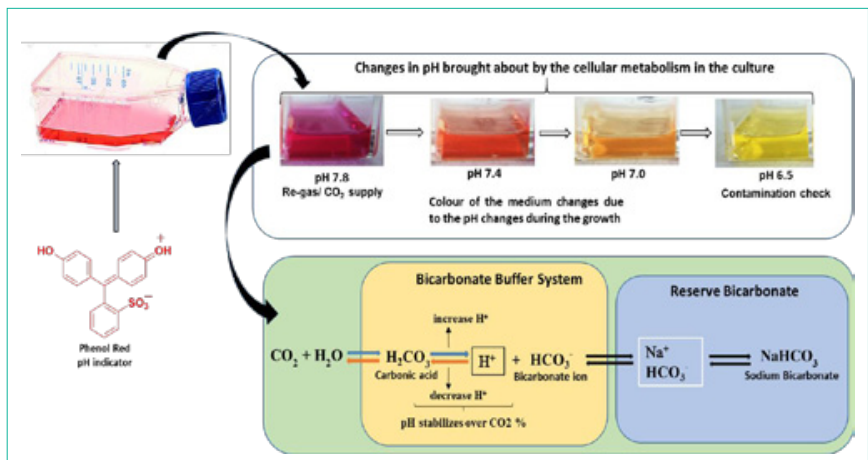

Image 1: Graphical Abstract.

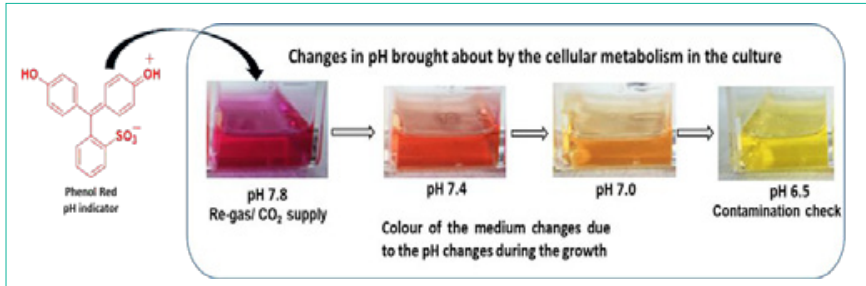

Figure 1: Changes in the colour of the medium at different $\mathrm{pH}$ intervals.

in their size and divide rapidly [42] (Table 3).

\section{Buffering system $\mathrm{CO}_{2} / \mathrm{HCO}_{3}$ -}

$\mathrm{CO}_{2} / \mathrm{HCO}_{3}^{-}$, usually used as a buffering system in the media, is preferred as a physiological and biological approach in the research. The exogenous buffer may have undesirable consequences to prevent, for example, long-term $\mathrm{CO}_{2}$ gradient toxicity regimes a realistic transmembrane in the buffer such as glycolytic medium stimulus in $\mathrm{Ca}^{2+}$ binding receptors to produce $\mathrm{CO}_{2}$ in cells. [40,47-49]. Cellular homeostasis is responsible for membrane transport, whereas the $\mathrm{HCO}_{3}^{-}$activates essential membrane ions additionally [50,51]. However, behavioral changes by the transduction mechanism modulate the extracellular $\mathrm{pH}$ as its sensitivity influences steady-state intracellular $\mathrm{pH}[43]$.

\section{Effect of $\mathrm{CO}_{2}$ in Growth}

In industries, cell culture reactors with carbon-dioxide maintain partial pressure of $150-200 \mathrm{mmHg}$, for inhibition of cell growth significantly, resulting, a proportional increase in osmolality by increased partial $\mathrm{CO}_{2}$ at constant $\mathrm{pH}$, due to balance with bicarbonate $\left(\mathrm{HCO}_{3}^{-}\right)$. The utilization of specific glucose and lactate production at $140 \mathrm{mmHg}$ of partial $\mathrm{CO}_{2}\left(\mathrm{pCO}_{2}\right)$ lowers by $40-50 \%$. At higher $\mathrm{pCO}_{2}$, the constraint of glycolysis develops because of lower byproduct levels and nutrient residue (higher) at lower cell density. It is 
correlated with oxygen intake and cell-specific glucose increase. Thus, the culture system varies with the evident effects of $\mathrm{pCO}_{2}$ [52].

The production of $\mathrm{CO}_{2}$ occurs through catabolic reactions for the required synthesis of fatty acids, pyrimidines, and purines. Media generally consist of vitamins, amino acids, salts, and other substances, such as $\mathrm{NaHCO}_{3}$, as an organic buffer substance. A balanced and stable $\mathrm{pH}$ value is required for the growth of cell cultures. Cell type varies from one cell type to another at the value of $\mathrm{pH}$ ideally during culturing. In an atmosphere of 5-10\% $\mathrm{CO}_{2}$, cells are grown using buffered media with $\mathrm{NaHCO}_{3}$ (sodium bicarbonate) and with ideal maintained $\mathrm{pH}$ 7.2-7.4 [1]. $\mathrm{CO}_{2}-\mathrm{HCO}_{3}^{-}$buffer acts as a base medium in this condition, as $\mathrm{pH}$ is dependent on the dissolved $\mathrm{CO}_{2}$ and the delicately balanced medium, which is responsible for altering the $\mathrm{pH}$ medium as changes occur in the atmospheric $\mathrm{CO}_{2}$ [8]. Depending on the amount of concentration, the corresponding amount of $\mathrm{CO}_{2}$ is gassed into the selected medium, and the supply is monitored to continue throughout the cell culture process for the required $\mathrm{pH}$ stability. The $\mathrm{pH}$ change in the medium against buffers controls cell growth [53].

Hydration of dissolved $\mathrm{CO}_{2}$ occurs in equilibrium with $\mathrm{HCO}_{3}^{-}$and $\mathrm{H}^{+}$. If $\mathrm{pH}$ is not controlled, acidification will cause in the medium by inhibition of $\mathrm{CO}_{2}$. If $\mathrm{pH}$ regulates by incorporating basic conditions, it shifts in the equilibrium reaction towards the right; in this case, $\mathrm{pCO}_{2}$ increases with osmolality [52] (Figure 2). The detrimental effect of cells shows high osmolality. However, the production of $\mathrm{CO}_{2}$ information is relatively studied in cultured cells $[54,55]$.

\section{Role of $\mathrm{CO}_{2}$ Incubator in pH Stability}

$\mathrm{CO}_{2}$ incubator is used for the culturing of cells for experimental purposes and maintains optimum $\mathrm{pH}$ under a sterile environment providing optimum temperature and moisture. In the medium, the carbonate buffer supports the constant $\mathrm{pH}$ release along with $\mathrm{CO}_{2}$ gas in the incubator. When the color changes in the media, changes can be seen in $\mathrm{pH}$, indicating that the altering of $\mathrm{CO}_{2}$ levels has occurred [1]. Usually, $4-10 \%$ of $\mathrm{CO}_{2}$ is used in the cell culture, and 5-7 \% of $\mathrm{CO}_{2}$ is used in air. For the proper $\mathrm{pH}$ and osmolality to achieve, the medium has to maintain $\mathrm{HCO}_{3}{ }^{-}$concentration and $\mathrm{CO}_{2}$ tension [56]. For example, if two or more people use the same incubator, then there will be a slight disturbance while opening and closing the door. The chamber interior affects the parameters of $\mathrm{CO}_{2}$ concentration, temperature, and humidity; even if the door is kept open for about 30 seconds. The standard atmosphere $(0.3 \%)$, which is attained with an immediate drop in $\mathrm{CO}_{2}$ concentration, shifts the $\mathrm{pH}$ value by itself within the growth medium. However, within a few minutes, the disturbances can remunerate rapidly for the climate balance. The reason for a highly adaptive and dynamic system with an IR sensor or adverse reactions in cell growth can appear when the system does not prevent it immediately. Measurement of the atmospheric air moisture is independent at an accurate time, and immediately $\mathrm{CO}_{2}$ contents are regulated [57].

Usually, after disturbance of air, it reduces relatively at the buildup humidity, in such conditions as often-opening doors or any other exposure to physical condition. However, the IR sensor with BINDER CB technology results in rapid recovery at times, and $\mathrm{pH}$ value ranging remains neutral. This phenomenon increases by

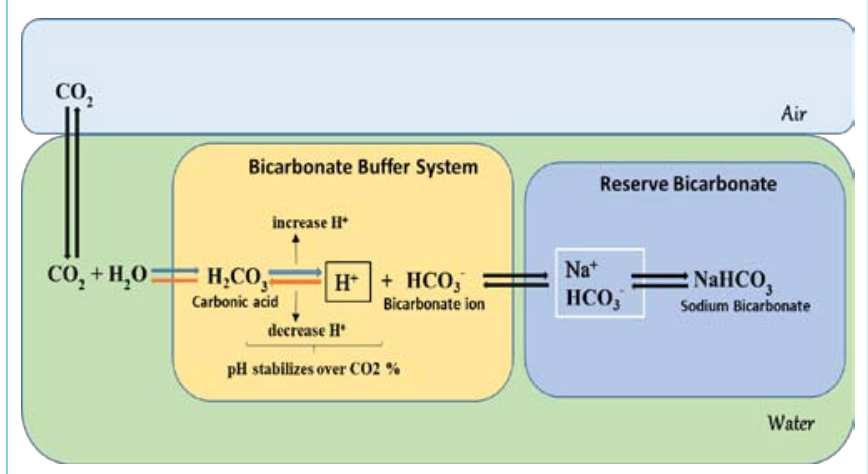

Figure 2: Mechanism of $\mathrm{CO}_{2}$ buffering system in cell culture.

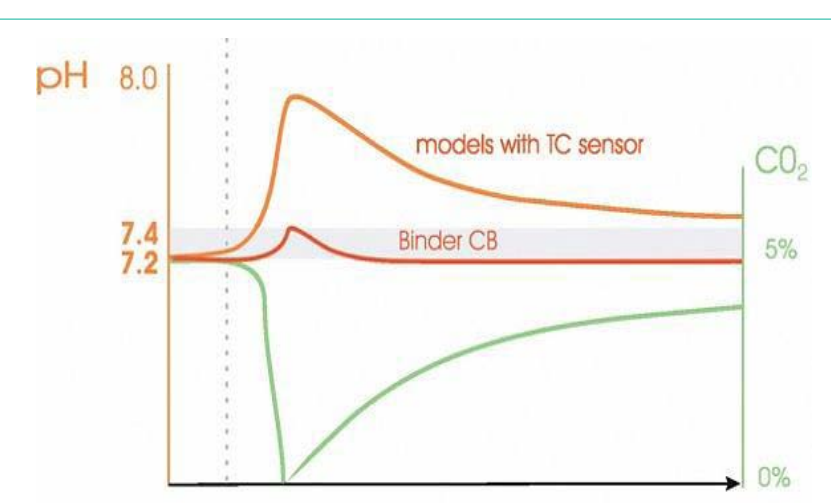

Figure 3: Rapid stabilization of the $\mathrm{pH}$ with an IR sensor vs. long recovery times in models with technologies for thermal conductivity sensors.

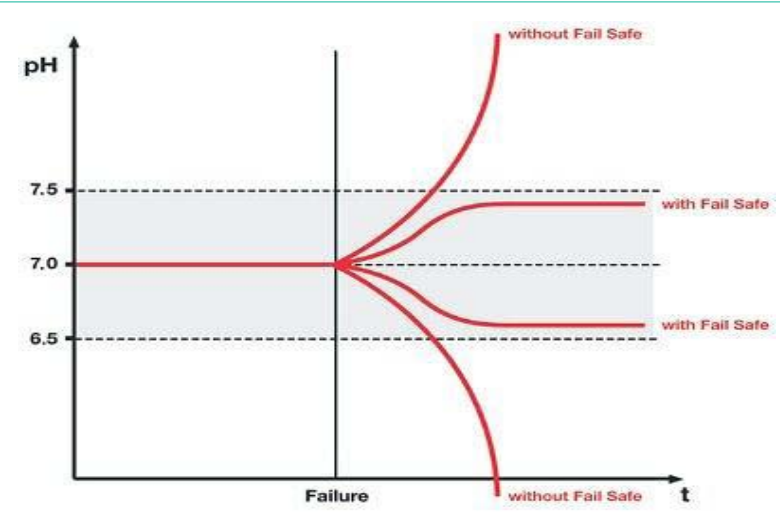

Figure 4: Possible consequences of a $\mathrm{CO}_{2}$ supply disturbance on the $\mathrm{pH}$ value of cell culture: the $\mathrm{pH}$ value may change to the alkaline range with a limited supply of gas (low $\mathrm{CO}_{2}$ ) or to the acid range with an excessive supply of gas (high $\mathrm{CO}_{2}$ ). Intelligent fail-safe ensures rapid harmonization.

opening the door. The kinetics explains the reaction of cell cultures when there is a disturbance in $\mathrm{CO}_{2}$ concentration. In an incubator, regulation of $\mathrm{CO}_{2}$ supply always is interpretative to cell safety. Above the tolerance limits, it is crucial to stop shifting the $\mathrm{pH}$ value into the alkali-acidic range during the long cultivation process at any time [57] (Figure 3).

Adverse effects in culture growth are attained after 4 hours post, which a downturn in the cell division as observed and can lead to cell death. Nevertheless, problems can occur when $\mathrm{CO}_{2}$ content changes are unnoticed in the incubator. In this regard, (Binder) 


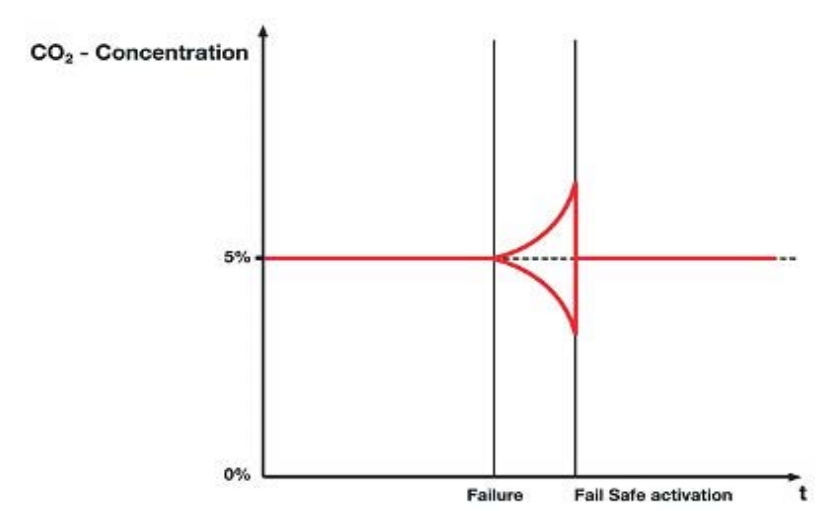

Figure 5: Rapid adaptation of the $\mathrm{CO}_{2}$ supply due to the activation of Intelligent Fail-Safe.

Intelligent Fail-Safe System may be the right solution, which may prove irreversible when there is no one in the lab. In the standard incubator, gas consumption information is stored to obtain necessary $\mathrm{CO}_{2}$ concentration and comparison of actual gas supply done with saved value consistently, during the operating the system [57] (Figure $4)$.

Intelligent Fail-safe controls the $\mathrm{CO}_{2}$ supply where it is too much or less gas difference in injecting $\mathrm{CO}_{2}$ and attains back to its original concentration value. Any changes in the gas supply, the system reacts immediately, signals before under concentration, or overconcentration of $\mathrm{CO}_{2}$ is triggered (+ or - target value) and rapidly controls the $\mathrm{pH}$ value (Figure 5). The reliability of the $\mathrm{pH}$ value is ensured in all situations, including after a controller or sensor defect. The Fail-Safe device is referred to as "Intelligent" because it tracks the production of $\mathrm{CO}_{2}$ individually and continuously throughout the process [57].

\section{Effect of $\mathrm{CO}_{2}$ in Cellular Metabolism}

Each cell has its mechanism and transport route in an organism, and the cells function effectively and efficiently when cellular respiration occurs appropriately in organisms [58]. The process of dilution of gas with the lipid bilayer occurs by a passive diffusion process. The gastric glandular cells in plants are impermeable to carbon dioxide; specific structures like aquaporin are found in the plasma membrane and the inner chloroplast membrane act as carbon dioxide $\left(\mathrm{CO}_{2}\right)$ channels [59].

In eukaryotes, the role of carbon dioxide is very crucial in maintaining the plasma $\mathrm{pH}$ homeostasis via the buffering capability of carbonic acid. The elevated carbon dioxide levels lead to a condition called hypercapnia, which is the result of an imbalance in $\mathrm{pH}$, leading to pathophysiological effects. Such effects appear at the organismal and cellular levels resulting in a varied response in many tissues, including lungs, kidneys, the central nervous system, the peripheral nervous systems, muscles, and blood cells [60].

The mechanism, such as glycolysis, protein synthesis, DNA synthesis, and exocytosis, a secretion, alter the proliferating cells' internal $\mathrm{pH}$ [61]. However, in an in-vitro experiment, which involves the growth of cells outside the body of the organism, high dissolved carbon dioxide $\left[\mathrm{dCO}_{2}\right]$ concentration, can lead to a significant problem causing growth inhibition, metabolic changes, and reduced productivity in mammalian cell culture [46]. The stabilization of the cytoplasmic $\mathrm{pH}$ in mammalian cells is controlled by the exchange of sodium and hydrogen $\left[\mathrm{Na}^{+} / \mathrm{H}^{+}\right]$and the presence of $\mathrm{HCO}_{3}$ - transport. Various enzyme systems, which are yet unknown, control the ionization states and activities, thus, affecting the $\mathrm{pH}$. The development of the sophisticated techniques, which is involved in the measurement of the intracellular $\mathrm{pH}$, such as microelectrodes [62,63], fluorescence [64-67], and nuclear magnetic resonance [68], made the understanding of the regulation of intracellular $\mathrm{pH}$ and its proliferation in cells very clear. However, many new dilemmas remain unknown.

A typically $\mathrm{dCO}_{2}$ level in a high-density mammalian cell perfusion culture reaches as high as $200 \mathrm{~mm} \mathrm{Hg}$ [69]. On the other hand, a dissolved carbon dioxide concentration of ca. $38 \mathrm{~mm} \mathrm{Hg}(5 \%)$ is adequate for mammalian cell growth [70]. Hence, the proliferative control of the $\mathrm{pH}$ is responsible for the characteristic phenotypic expression by the cells.

\section{Implications on Other Environmental Factors}

In mammalian bioprocess, the respiratory product is $\mathrm{CO}_{2}$, which is, consequently, unavoidable. Cellular activity depends on $15-20 \%$ of aeration, in which $\mathrm{CO}_{2}$ fraction flow in the exhaust gas. Bioreactors filled the height up to $10-15 \mathrm{~m}$ and $0.5-2$ bar with overpressure microbial fermentation, taking into consideration the 1-1.5 bar hydrostatic pressure. The $\mathrm{pCO}_{2}$ value hits at $0.1-0.6$ bar at the bottom of the bioreactors. Notably, such costs decrease if fresh air is correctly collected [41].

The experimental data revealed that the effects of biomass, growth of substrate yields, cell division, product development, and morphology reported changes in osmolality in the media with coeffects in combination, which were due to the elevated $\mathrm{pCO}_{2}$ pressure point [71]. Individual phenotypic studies observed the rate of fundamental growth kinetics of strains showing a decline in the count of insect cells, as high dissolved $\mathrm{CO}_{2}$ concentration were present, due to which growth was inhibited rather than cell death, as $90 \%$ of the cell were viable all times [41].

In large-scale bioreactors, cells frequently circulate when $\mathrm{pCO}_{2}$ level changes, i.e., by pseudo-stationary scale is usually not stimulated. The cultivated mammalian cells are limited in contrast to the microbial application owing to the small scale of bioreactors and cell operation [72]. Many types of research have studied on elucidating of $\mathrm{pCO}_{2}$ levels on microbes and mammalian cultures $[42,73]$.

Monoclonal antibody development by hybridoma cell culture, performed at the industrial level, can achieve high cell density in largescale reactors, a problem induced by $\mathrm{CO}_{2}$ accumulation. The elevated level of $\mathrm{pCO}_{2}$ is present with or without compensation of osmolality. Well, the synthesis of an antibody in plate cultures consists of glucose metabolism, and death in hybridoma cells, which is the consequence of a rapid increase in osmolality and partial pressure of carbon dioxide $\left(\mathrm{pCO}_{2}\right)$, which often involve improvements in oxygen consumption. For further characterization, batch and continuous experiments are carried out in controlled bioreactors [52]. 


\section{Significance and Future Directions}

Cell culture plays a crucial role in modern-day research, and thereby understanding the mechanism of the gross complexity within an organism can be simplified and easily understood using this technique. A significant role played by a researcher is observing in maintaining of an uncontaminated/less contaminated zone during the flow of the protocol. Following points may be of great significance in this regard:

- The mechanism of understanding the gross complexity within an organism can be simplified with the usage of an in- vitro setup of cell culture.

- The replication of sustainable environmental conditions plays a crucial role in modulating the changes desired for the growth, proliferation, or differentiation depending upon the need for an experiment.

- The usage of cell lines implicates and plays a crucial role in mimicking an in-vivo model and helps in understanding the modulations and changes effectively than a primary culture.

- The constitutive role of $\mathrm{CO}_{2}$ incubator is seen as a limiting factor in ensuring the maintenance of the $\mathrm{pH}$ and active development of the cell cultures.

- An approach to maintain a healthy and ethical culture is to practice a proper laboratory handling and media preparation protocol, ensuring a contaminant free media with an optimal seeding density to prevent exhaustion of nutrients for the cell.

- Along with the culture media, temperature, humidity, seed density of a particular cell type $\mathrm{pH}$, and $\mathrm{CO}_{2}$ along with the buffering system involved plays a vital role in the regulation of the variability among the cells. $\mathrm{CO}_{2}$ incubator achieves the osmolality, $\mathrm{pH}$, and maintaining moisture content.

- The cellular metabolism and production of competent metabolites carbon dioxide are essential. Alternation in it can result in $\mathrm{pH}$ imbalance leading to acidification and changing the osmolarity.

- The development of sophisticated techniques like NMR, microelectrodes, and fluorescence enables in the measurement of intracellular $\mathrm{pH}$ and requires a gross study to understand the unknown process yet to be discovered.

\section{Conclusion}

The review portrays a descriptive organization of data upon the limitations of the use of carbon dioxide in an in-vitro condition. For the effective functioning of many tissues and cells, carbon dioxide is an essential factor; an attempt was made on the brief comparison of $\mathrm{pCO}_{2}, \mathrm{dCO}_{2}$ and high levels of $\mathrm{CO}_{2}$ upon the seeding density of the cells. Their role is least described in many reports and studied. The data collected regarding the protective effects of hypercapnia and efficiency of the carbon dioxide are less explored aspects, and hence a need to understand the process is required. An elaborate study focusing on the importance of adequate percentage (5\%) $\mathrm{pCO}_{2}$ to maintain cell culture and metabolic influx in an in-vitro system is lacking. In order to attain an understanding of cell physiology and develop cell culture processes, the emphasized areas need to be pondered upon and experimented, which would unravel various aspects, which remains unexplored.

\section{Highlights}

- Variations among the factors in the cell culture environment affect both the cellular and the physiological integrity of the cells.

- Reduction in cellular growth with the variation of $\mathrm{CO}_{2} /$ $\mathrm{HCO}_{3}^{-}$is a regular phenomenon in several biological processes, susceptible to acid-base chemistry.

- $\mathrm{CO}_{2} / \mathrm{HCO}_{3}^{-}$levels limit anaplerotic reactions inside the biological systems.

- Imbalance in $\mathrm{pH}$ due to variation in $\mathrm{CO}_{2}$ levels inside the cells leads to hypercapnia that integrates the pathophysiological effects.

\section{References}

1. Nema R, Khare S. An animal cell culture: Advance technology for modern research. Advances in Bioscience and Biotechnology. 2012; 3: 219-226.

2. Pardee $A B$. The cell surface and fibroblast proliferation some current research trends. Biochim Biophys Acta. 1975; 417: 153-172.

3. Phelan MC. Techniques for mammalian cell tissue culture. Current protocols in molecular biology. 2006. 74: A.3F.1-A.3F.18.

4. Costlow $\mathrm{M}$, Baserga R. Changes in membrane transport function in $\mathrm{G}_{\mathrm{o}}$ and $\mathrm{G}$ cells. J. Cell. Physiol. 1973; 82: 411-420.

5. Philippeos C, Hughes RD, Dhawan A \& Mitry RR. Introduction to cell culture Methods in molecular biology. 2011; 806: 1-13.

6. Drexler HG, Uphoff CC. Contamination of cell culture, mycoplasma Encyclopedia of cell technology. Edited by: Spier RE. New York, John Wiley \& Sons, Inc., 2000: 609-627.

7. Tramacere M, Borghetti AF, Guidotti GG. Serum-mediated regulation of amino acid transport in cultured chick embryo fibroblasts. Journal of cellular physiology. 1977; 93: 425-433.

8. McGarrity GJ. Spread and control of mycoplasmal infection of cell cultures In-vitro Cell. Dev. Biol. -Plant. 1976; 12: 643-648.

9. Kletzien RF, Perdue JF. Sugar transport in chick embryo fibroblasts. I. A functional change in the plasma membrane-associated with the rate of cell growth. The Journal of biological chemistry. 1974; 249: 3366-3374.

10. David LN, Michael MC. Principles of Biochemistry (4 $4^{\text {th }}$ edition), New York: WH Freeman. 2005; 23: 293-294.

11. Yang Z, Xiong HR. Culture Conditions and Types of Growth Media for Mammalian Cells. 2012

12. Salazar A, Keusgen $M$, von Hagen J. Amino acids in the cultivation of mammalian cells. Amino acids. 2016; 48: 1161-1171.

13. Yao T, Asayama Y. Animal-cell culture media: History, characteristics, and current issues. Reproductive medicine and biology. 2017; 16: 99-117.

14. Zelzer M, Albutt D, Alexander MR, Russell NA. The Role of Albumin and Fibronectin in the Adhesion of Fibroblasts to Plasma Polymer Surfaces. Plasma Processes and Polymers. 2011; 9: 149-156.

15. Ryu AH, Eckalbar WL, Kreimer A. Use antibiotics in cell culture with caution genome-wide identification of antibiotic-induced changes in gene expression and regulation. Sci Rep. 2017; 7: 7533.

16. Büntemeyer $\mathrm{H}$, Lehmann J. The Role of Vitamins in Cell Culture Media Editors. In: Lindner-Olsson E, Chatzissavidou N, Lullau E. Animal Cell Technology: From Target to Market. ESACT Proceedings. 2001; 1.

17. Schuldiner M, Yanuka O, Itskovitz-Eldor J, Melton DA \& Benvenisty N. Effects of eight growth factors on the differentiation of cells derived from human embryonic stem cells. Proceedings of the National Academy of Sciences. 2000; 97: 11307-11312. 
18. Roscoe DH, Bell GM. Use of a pH indicator in protoplast culture medium. Plant Science Letters. 1981; 21: 275-279.

19. Bell C, Paul M Quinton. Effects of Media Buffer Systems on Growth and Electrophysiologic Characteristics of Cultured Sweat Duct Cells. In-vitro Cellular \& Developmental Biology. 1991; 27A: 47-54.

20. Dulbecco R, Stoker MGP. Conditions determining the initiation of DMA synthesis in 3T3 cells. Proc. Nati. Acad. Sci. USA. 1970; 66: 204-210.

21. Todaro GJ, Lazar GK, Green H. The initiation of cell division in a contactinhibited mammalian cell line. Journal of cellular physiology. 1965; 66: 325-

22. Foster DO, Pardee AB. Transport of amino acids by confluent and nonconfluent 3 T3 and polyoma virus-transformed 3 T3 cells growing on glass coverslips. The Journal of biological chemistry. 1969; 244: 2675-2681.

23. Perdue JF. Transport across serum-stimulated and virus-transformed cell membranes. In: C. Nicolau (Ed.). Virus-transformed Cell Membranes. London: Academic Press. 1978: 185-280.

24. Weber MJ, Rubin $\mathrm{H}$. Uridine transport and RNA synthesis in growing and density-inhibited animal cells. Journal of cellular physiology. 1971; 77: 157168.

25. Holley RW. A unifying hypothesis concerning the nature of malignant growth Proceedings of the National Academy of Sciences. 1972; 69: 2840-2841.

26. Pardee AB. Cell Division and a Hypothesis of Cancer. National Cancer Institute monograph. 1964; 14: 7-20.

27. Piedimonte G, Borghetti AF, Guidotti GG. Effect of Cell Density on Growth Rate and Amino Acid Transport in Simian Virus 40-transformed 3T3 Cells. Cancer Res. 1982; 42: 4690-4693.

28. Shodell M, Isselbacher K. Effect of different media supplements on amino acid uptake and mitotic stimulation in BHK cells. Nature: New biology. 1973 243: 83-85.

29. Stoker MG, Rubin H. Density-dependent inhibition of cell growth in culture. Nature. 1967; 215: 171-172

30. Cobo F, Stacey GN, Hunt C, et al. Microbiological control in stem cell banks: approaches to standardization. Appl Microbial Biotechnol. 2005; 68: 456-466.

31. Schlaeger EJ. Medium design for insect cell culture. Cytotechnology. 1996; 20: $57-70$.

32. Donaldson MS, Shuler ML. Low-cost serum-free medium for the BTI-Tn5B1-4 insect cell line. Biotechnology Progress. 1998; 14: 573-579.

33. Masters JR, Stacey GN. Changing medium and passaging cell lines. Nature protocols. 2007; 2: 2276-2284.

34. Cunningham DD, Pardee AB. Transport changes rapidly initiated by serum addition to "contact inhibited" ЗT3 cells. Proceedings of the National Academy of Sciences. 1969; 64: 1049-1056.

35. Molina D, de Carvalho JC, Júnior AIM, Faulds C, Bertrand E, Soccol CR. Biological contamination and its chemical control in microalgal mass cultures Appl Microbiol Biotechnol. 2019; 103: 9345-9358.

36. Raymond WN, Price PJ. Best practices for detecting and mitigating the risk of cell culture contaminants, In-Vitro Cell. Dev Biol Anim. 2017; 53: 872-879.

37. Pardee AB, Dubrow R, Hamlin JL, Kletzien RF. Animal cell cycle. Annual review of biochemistry. 1978; 47: 715-750.

38. Freshney RI. Defined Media and Supplements Culture of Animal Cells: A Manual of Basic Technique and Specialized Applications, Sixth Edition John Wiley \& Sons. 2010: 99-114.

39. Zigler JS, Lepe-Zuniga JL, Vistica B, Gery I. Analysis of the cytotoxic effects of light-exposed HEPES-containing culture medium. In vitro cellular \& developmental biology: Journal of the Tissue Culture Association. 1985; 21 282-287.

40. Hanrahan JW, Tabcharani JA. Inhibition of an outwardly rectifying anion channel by HEPES and related buffers. The Journal of membrane biology. 1990; 116: 65-77.
41. Vajrala Sucheta Gowthami. "Mechanism of $\mathrm{CO}_{2}$ inhibition in insect cell culture." MS (Master of Science) thesis, University of Iowa. 2010.

42. Gray DR, Chen S, Howarth W, Inlow D, Maiorella BL. $\mathrm{CO}_{2}$ in large-scale and high-density CHO cell perfusion culture. Cytotechnology. 1996; 22: 65-78.

43. Michl J, Park KC, Swietach P. Evidence-based guidelines for controlling $\mathrm{pH}$ in mammalian live-cell culture systems. Communications Biology. 2019; 2: 144

44. Auslander D, Ausländer S, Charpin-El Hamri G, Sedlmayer F, Müller M, Frey $\mathrm{O}$, et al. A synthetic multifunctional mammalian $\mathrm{pH}$ sensor and $\mathrm{CO}_{2}$ transgene-control device. Molecular cell. 2014; 55: 397-408.

45. Chen CC, Bates R, Carlson J. Effect of environmental and cultural conditions on medium $\mathrm{pH}$ and explant growth performance of Douglas-fir (Pseudotsuga menziesii) shoot cultures. 2015; 3: 298.

46. Garnier A, Voyer R, Tom R, Perret S, Jardin B, Kamen A. Dissolved carbon dioxide accumulation in a large scale and high-density production of TGF? The receptor with baculovirus-infected Sf-9 cells. Cytotechnology. 1996; 22 : 53-63.

47. Ferguson WJ, Braunschweiger $\mathrm{KI}$, Braunschweiger WR, Smith JR, McCormick JJ, Wasmann CC, et al. Hydrogen ion buffers for biological research. Analytical Biochemistry. 1980; 104: 300-310.

48. Lepe-Zuniga JL, Zigler JS, Gery I. Toxicity of light-exposed HEPES media Journal of immunological methods. 1987; 103: 145.

49. Stea A, Nurse CA. Contrasting effects of HEPES vs $\mathrm{HCO}_{3}^{-}$buffered media on whole-cell currents in cultured chemoreceptors of the rat carotid body. Neuroscience Letters. 1991; 132: 239-242.

50. Boron WF. Regulation of intracellular $\mathrm{pH}$. Advances in physiology education 2004; 28: 160-179

51. Thomas RC. Cell growth factors. Bicarbonate and $\mathrm{pH}$ response. Nature. 1989; 337: 601

52. de Zengotita VM, Kimura R, Miller WM. Effects of $\mathrm{CO}_{2}$ and osmolality on hybridoma cells: growth, metabolism, and monoclonal antibody production. Cytotechnology. 1998; 28: 213-227.

53. Hopkins E, Sharma S. Physiology, Acid-Base Balance. In: StatPearls. Treasure Island (FL): StatPearls Publishing. 2020.

54. Kurano N, Leist C, Messi F, Kurano S, Fiechter A. Growth behaviour of Chinese hamster ovary cells in a compact loop bioreactor: 1 . Effects of physical and chemical environments. Journal of Biotechnology. 1990; 15: 101-111.

55. Ozturk SS. Engineering challenges in high-density cell culture systems. Cytotechnology. 1996; 22: 3-16.

56. Pohjanpelto $P$. Putrescine transport is greatly increased in human fibroblasts initiated to proliferate. The Journal of cell biology. 1976; 68: 512-520.

57. Maurer D. The Significance of $\mathrm{pH}$ Stability for Cell Cultures. American Laboratory. 2005

58. Cherniack NS, Longobardo GS. Oxygen and carbon dioxide gas stores of the body. Physiological Reviews. 1970; 50: 196-243.

59. Uehlein N, Otto B, Hanson DT, Fischer M, McDowell N, Kaldenhoff R. Function of Nicotiana tabacum aquaporins as chloroplast gas pores challenges the concept of membrane $\mathrm{CO}_{2}$ permeability. The Plant cell. 2008; 20: 648-657.

60. Eaton DC, Pooler JP. Regulation of Hydrogen Ion Balance. In: Eaton D, Pooler J, eds. Vander's Renal Physiology, 7ed: The McGraw-Hill Companies, Inc. 2009.

61. Busa WB. Mechanisms and consequences of $\mathrm{pH}$-mediated cell regulation. Annual review of physiology. 1986; 48: 389-402.

62. Thomas RC. Ion- Sensitive Intracellular Microelectrode: How to make and use them. New York. 1978.

63. Ammann D. Potentiometric Measurements of Ion Activities with Neutral Carrier-Based Electrodes. In: Ion-Selective Microelectrodes. Advances in Experimental Medicine and Biology. 1986; 50. Springer, Berlin, Heidelberg

64. Eidelman O, Cabantchik Zl. Continuous monitoring of transport by 
fluorescence on cells and vesicles. Biochimica et Biophysica Acta. 1989; 988: 319-334.

65. Tsien RY. Fluorescent indicators of ion concentrations. Methods in cell biology. 1989; 30: 127-156.

66. Martínez-Zaguilán R, Martínez GM, Lattanzio F \& Gillies RJ. Simultaneous measurement of intracellular $\mathrm{pH}$ and $\mathrm{Ca}^{2+}$ using the fluorescence of SNARF-1 and fura-2. American Journal of Physiology. 1991; 260: C297-C307.

67. Martinez-Zaguilan. Measurements of intracellular $\mathrm{Ca}^{2+}$ and $\mathrm{pH}$ in cultured cells by fluorescence spectroscopy; Editor. In: Watson RR, in vitro Methods of Toxicology. Boca Raton, CRC Press. 1992.

68. Gillies RJ, Alger JR, den Hollander JA, Shulman RG. Intracellular pH measured by NMR: methods and results. Kroc Foundation series. 1981; 15 79-104.

69. Taticek R, Petersen S, Konstantinov K, Naveh D. Effect of dissolved carbon dioxide and bicarbonate on mammalian cell metabolism and recombinant protein productivity in high-density perfusion culture. ACS Annual Meeting San Diego, CA. 1998.
70. Guyton AC, Hall JE. Introduction to physiology: the cell and general physiology. Textbook of Medical Physiology. Philadelphia: W. B. Saunders Company. 2011: 6-7.

71. Blombach B, Takors R. $\mathrm{CO}_{2}$-Intrinsic Product, Essential Substrate, and Regulatory Trigger of Microbial and Mammalian Production Processes. Frontiers in Bioengineering and Biotechnology. 2015; 3: 108.

72. Zhu MM, Goyal A, Rank DL, Gupta SK, Vanden Boom T, Lee SS. Effects of elevated $\mathrm{pCO}_{2}$ and osmolality on the growth of $\mathrm{CHO}$ cells and production of antibody-fusion protein B1: a case study. Biotechnology Progress. 2005; 21: 70-77.

73. Dixon NM, Kell DB. The inhibition by $\mathrm{CO}_{2}$ of the growth and metabolism of microorganisms. J. Appl. Bacteriol. 1989; 67: 109-136. 